\title{
Management of Patients with Heart Failure and Depression: a Systematic Review
}

\author{
Débora Laésia Saraiva Ribeiro', \\ Sylvia Rannyelle Teixeira Lima', \\ Geniefesson Leandro da Silva Feitoza ${ }^{1}$, \\ João Vitor Cândido Pimentel ${ }^{2}$, Herbert Lima Mendes ${ }^{1}$, \\ Modesto Leite Rolim Neto ${ }^{1,2}$
}

\section{Abstract}

Background: Heart failure (HF) is a chronic and incapacitant disease with bad prognosis, and it is commonly related to psychosocial comorbidities that difficult treatment adhesion. The prevalence of depression in HF varies from 20 to $40 \%$, occurring 3 to 5 times more frequently in patients with HF than general population. The coexistence of depressive symptoms depreciates heart condition in patients with HF: depressive symptoms predict mortality, re-hospitalization, and an augment of symptoms in those patients. Aiming to clarify certain aspects of this comorbidity, it was performed a systematic review using Scopus and MEDLINE/PubMed databases, correlating HF and depression, from January 1, 2013, to August 20, 2017, by means of the descriptors found in MeSH: "heart failure" and "depression".

Methods: Data screening applied combinations, as follows: \#1. "Heart Failure" [MeSH Terms]; \#2. "Depression" [MeSH Terms]; \#3. "Management" [Keyword], using the following research strategy: (\#1 AND \#2) AND \#3.

Results: Improvement in depression levels through interventions using telephone is extensively reported in literature, based on providing information about the disease, self-care accompaniment, or cognitive behavioral therapy (CBT). Because of this, it is shown as an effective alternative in depression, improving surviving rates. Equally effective interventions were the empowering of the patient and the familial engagement in caring, palliative care and multidisciplinary participation in construction of caring program.
1 Faculty of Medicine of Juazeiro do Norte, Estácio FMJ, Juazeiro do Norte, Ceará, Brazil.

2 Federal University of Cariri, Faculty of Medicine of Barbalha, Barbalha, Ceará, Brazil.

Contact information:

Modesto Leite Rolim Neto.

Address: Universidade Federal do Cariri, UFCA. Faculdade de Medicina.

”modestorolim@yahoo.com.br 
Conclusions: Curiously, physical exercises did not show, statistically, efficiency in depression improvement, and few were the articles approaching antidepressant medications use in this class of patient.

\section{Keywords}

Heart Failure; Depression; Management.

\section{Introduction}

Approximately $2 \%$ of general population suffer from Heart Failure (HF). This incidence is higher for 1 among 10 people with over than 75 years old (Lundgren et al., 2015; McMurray et al., 2012a).

Despite treatment advances, HF has high morbidity and mortality rates, as well as leads to repetitive hospital admissions (Bekelma et al., 2014; Jaarsma et al., 2000). Mortality rate in 5 years is $50 \%$ for recently diagnosed patients, in the last 20 years (Greene et al., 2015; Kemper, Carmin, Metha \& Binkley, 2016).

$\mathrm{HF}$ is a complex clinical syndrome characterized by dyspnea and fatigue, and evidences subjacent structural abnormality or cardiac dysfunction (McMurray et al., 2012b; Tully, Selkow, Bengel \& Rafanelli, 2015). It is a chronic and incapacitant disease, with bad prognosis and a severely prejudiced quality of life (Bleumink et al., 2004; Lossnitzer et al., 2015). Other studies (Adams et al., 2005; Chamberlain et al., 2015; Kemper et al., 2016) add that many times HF is accompanied by other psychosocial comorbidities that difficult treatment adhesion.

Facing this, Tully et al. (2015) highlight that is common the prevalence of depression in HF. Some studies show a prevalence varying from 20 to $40 \%$ (Johansson, Dahlstrom \& Brostrom, 2006; Lundgren et al., 2015; Rutledge, Reis, Linke, Greenberg \& Mills, 2006). According other data, Gelbrich et al.
(2014) and Rutledge et al. (2006) depression occur 3 to 5 times more frequently in patients with HF than the general population, depending on symptoms severity of HF and comorbidities.

Interrelation between depressive symptoms and adverse cardiac outcome is firmly stablished (Gelbrich et al., 2014). Studies (Jiang et al., 2001; Jünger et al., 2005; Lossnitzer et al., 2015) corroborate this idea, once the coexistence of depressive symptoms depreciates heart condition in patients with HF: depressive symptoms predict mortality, re-hospitalization, and an augment of symptoms in those patients. Besides, depression is associated to higher health costs, significantly harms quality of life, has negative impacts in disease management strategies and is associated to lower rates of treatment adhesion (Bekelma et al., 2015; Huffman et al., 2014; Tully et al., 2015).

In this sense, recent researches are more and more focused in effects of depression treatment in patient with HF (Dekker, 2011; Lossnitzer et al., 2015; Thombs et al., 2008). Many studies report positive effects to several non-pharmacological depression treatments in patients with HF (Dekker, Moser, Peden \& Lennie, 2012; Lossnitzer et al., 2015; Rutledge et al., 2006; Thombs et al., 2008). Some researches also encountered an improvement of cardiac outcomes and clinical symptoms, as consequence of depression treatment (Dekker et al., 2012; Lossnitzer et al., 2015; Sullivan et al., 2009) 
Thus, this paper aimed to answer the following question: How to manage a patient with heart failure and depression? For that, a systematic review of the studies approaching this theme was performed, in order to show the best methods that can manage this comorbidity, and how these methods are applied in clinical practice.

\section{Method}

This is a systematic review following Cochrane Handbook and Meta-Analyzes (PRISMA) guidelines recommendations for conduction the systematic review. Previously chosen inclusion/exclusion criteria were adopted to analyze data present in Scopus and MEDLINE/PubMed databases, due their data coverage regarding heart failure and depression.

The search was conducted from January 1, 2013, to August 20, 2017, by means of the descriptors found in MeSH: "heart failure" and "depression". Also, after a brief analyzes of what word must be used to successfully gather the full information required in our search, the keyword "management" was used. Data screening applied combinations and gray literature, as follows: \#1. "Heart Failure" [MeSH Terms]; \#2. "Depression" [MeSH Terms]; \#3. "Management" [Keyword], using the following research strategy: (\#1 AND \#2) AND \#3.

The formulation of the research question was structured based on the PICO acronym. Each word of the PICO component means: P: patients diagnosed with heart failure and depression; I: management methods applied; C: collection of the available scientific information from January 1, 2013 to August 20, 2017; O: gather reliable information to correctly orientate health professionals when dealing with this kind of patient. The research question consists in: "How is the correct management of patients with diagnosed heart failure and depression?" The following types of studies were included: Case Reports, Clinical Study, Clinical Trial, Comparative
Study, Controlled Clinical Trial, Evaluation Studies, Journal Article, Multicenter Study, Observational Study, Randomized Controlled Trial, Twin Study, whose main theme was management of patients with heart failure and depression, in English language. This search period was chosen to gather the most recent information regarding the management of these patients, aiming to recover the most updated data and to build a consistent analysis. Exclusion criteria were comprised of articles that did not directly approach the management of patients with diagnosed heart failure and depression, studies that did not have the open access availability to full text and studies with different type of design. Studies were chosen through electronic search in Scopus and MEDLINE/PubMed databases.

Throughout the process of study selection, two reviewers worked independently and analyzed the studies to be included. When there was a disagreement between them, a third reviewer was used to make the final assessment on the inclusion or non-inclusion of the study. The entire content of the chosen studies was analyzed.

\section{Results}

Based on research strategy, 209 publications were identified at MEDLINE and 316 at Scopus, resulting in 525 publications. After an analysis of the title, abstract and body of the remaining references based on inclusion criteria of the study, 508 articles were excluded, and 17 studies remained in final sample. Repeated articles were computed only once in the final counting.

Figure 1 (flow diagram) presents an overview of the studies included in the final table and the elements used in the analysis process. Also, Table 1 shows an overview of selected articles as well as their main findings, methods of control and data publication 
Figure 1: Flow diagram summarizing the process of study inclusion in this review.

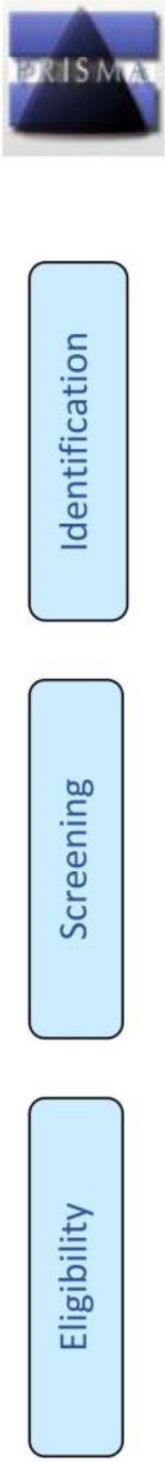

Records identified through MEDLINE database searching $(n=209)$

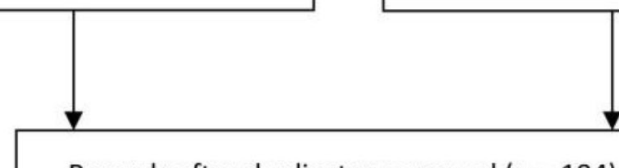

Records after duplicates removed $(n=104)$
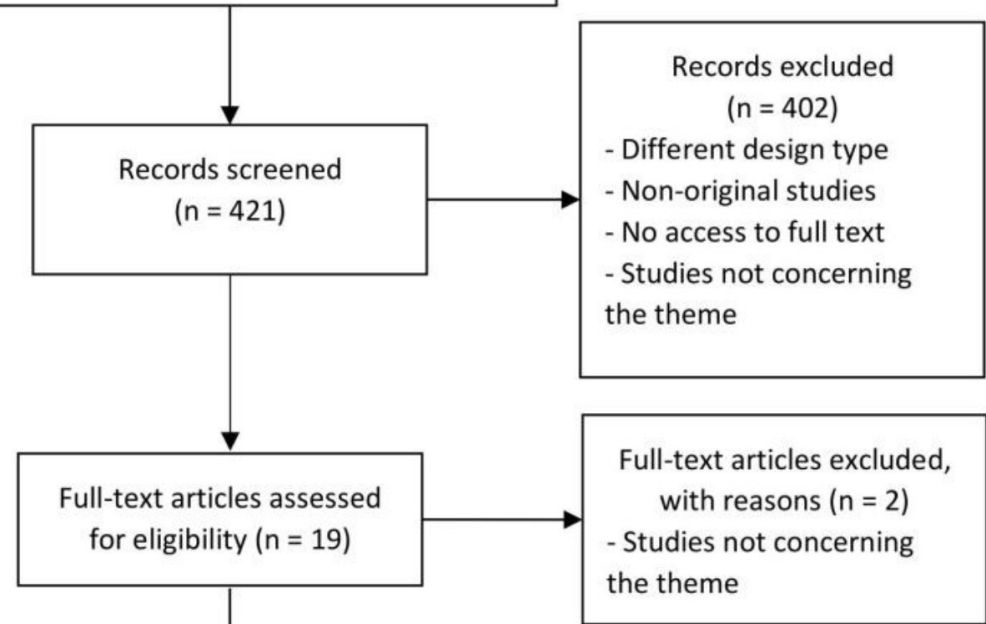

Studies included in quantitative analysis (metaanalysis) $(n=17)$

From: Moher d, Liberati A, Tetzlaff J, Altman DG, The PRISMA Group (2009). Preferred Reporting Items for Systematic Reviews and Meta-Analyses: The PRISMA Statement. Plos Med 6(7): e1000097. doi: 10.1371/journal.pmed1000097.

Source: Developed by the authors (2017) 
Table 1. Management of the comorbidity Heart Failure and Depression in the MEDLINE/PubMed and Scopus databases: main findings and limitations.

\begin{tabular}{|c|c|c|c|c|c|c|c|}
\hline Authors & Year & Title & Journal & Sample or comments & Main findings & Database & Limitations \\
\hline $\begin{array}{l}\text { Kalter- } \\
\text { Leibovici } \\
\text { O. et al. } \\
\text { [33] }\end{array}$ & 2017 & $\begin{array}{l}\text { Disease } \\
\text { management in } \\
\text { the treatment } \\
\text { of patients with } \\
\text { chronic heart } \\
\text { failure who have } \\
\text { universal access } \\
\text { to health care: } \\
\text { A randomized } \\
\text { controlled trial }\end{array}$ & BMC Medicine & $\begin{array}{l}\text { In this multicenter open-label } \\
\text { trial, } 1,360 \text { patients recruited } \\
\text { after hospitalization for heart } \\
\text { failure exacerbation ( } 38 \%) \text { or } \\
\text { from the community }(62 \%) \text { were } \\
\text { randomly assigned to either disease } \\
\text { management or usual care. }\end{array}$ & $\begin{array}{l}\text { Patients assigned to disease management } \\
\text { had a better health-related quality of life and } \\
\text { a lower depression score during follow-up. } \\
\text { This comprehensive disease management } \\
\text { intervention was not superior to usual care } \\
\text { with respect to the primary composite } \\
\text { endpoint, but it improved health-related } \\
\text { quality of life and depression. }\end{array}$ & Scopus & $\begin{array}{l}\text { The patients assigned to usual care were } \\
\text { evaluated by the cardiologists at the heart } \\
\text { failure centers every } 6 \text { months during } \\
\text { follow-up, thus some contamination of } \\
\text { the control intervention may be possible. } \\
\text { In addition, the follow-up assessments } \\
\text { of the patients' NYHA classification and } \\
6 \text {-minute walk test were performed by } \\
\text { assessors who were not blinded to the } \\
\text { patients' assigned intervention. }\end{array}$ \\
\hline $\begin{array}{l}\text { Kemper } \\
\text { KJ et al. } \\
{[9]}\end{array}$ & 2016 & $\begin{array}{l}\text { Integrative } \\
\text { Medical } \\
\text { Care Plus } \\
\text { Mindfulness } \\
\text { Training for } \\
\text { Patients With } \\
\text { Congestive } \\
\text { Heart Failure: } \\
\text { Proof of } \\
\text { Concept. }\end{array}$ & $\begin{array}{l}\text { J Evid Based } \\
\text { Complementary } \\
\text { Altern Med. }\end{array}$ & $\begin{array}{l}\text { Received care at our academic } \\
\text { medical center's Cardiomyopathy } \\
\text { Clinic and had been discharged } \\
\text { from hospital within the past } 12 \\
\text { months for symptoms of heart } \\
\text { failure. Five patients enrolled in the } \\
2013 \text { session and } 6 \text { enrolled in the } \\
2014 \text { session; overall, } 3 \text { dropped } \\
\text { out for a } 73 \% \text { completion rate. Of } \\
\text { the } 10 \text { patients who completed } \\
\text { baseline questionnaires, } 5 \text { (50\%) also } \\
\text { completed follow-up questionnaires. }\end{array}$ & $\begin{array}{l}\text { The most common comorbidities were weight } \\
\text { gain, sleep problems, and fatigue. After the } \\
\text { sessions, } 100 \% \text { of patients planned to make } \\
\text { changes to their diet, exercise, and stress } \\
\text { management practices. Over half of the } \\
\text { patients who met with a pharmacist had a } \\
\text { medication-related problem. Improvements } \\
\text { were observed in depression, fatigue, and } \\
\text { satisfaction with life }\end{array}$ & Pubmed & $\begin{array}{l}\text { As a proof of concept project, this study } \\
\text { suffers from a small sample size and } \\
\text { use of changing measures to assess key } \\
\text { outcomes as we adapted the assessment } \\
\text { based on participant feedback. The } \\
\text { project was carried out at a single } \\
\text { academic institution and included } \\
\text { only short-term self-reported outcome } \\
\text { measures; }\end{array}$ \\
\hline $\begin{array}{l}\text { Piette } \\
\text { JD et al. } \\
{[34]}\end{array}$ & 2015 & $\begin{array}{l}\text { A Mobile Health } \\
\text { Intervention } \\
\text { Supporting } \\
\text { Heart Failure } \\
\text { Patients and } \\
\text { Their Informal } \\
\text { Caregivers: A } \\
\text { Randomized } \\
\text { Comparative } \\
\text { Effectiveness } \\
\text { Trial. }\end{array}$ & $\begin{array}{l}\text { J Med Internet } \\
\text { Res. }\end{array}$ & $\begin{array}{l}\text { We identified } 331 \mathrm{HF} \text { patients from } \\
\text { Department of Veterans Affairs } \\
\text { outpatient clinics. }\end{array}$ & $\begin{array}{l}\text { Composite quality of life scores was similar } \\
\text { across arms. mHealth+CP patients were less } \\
\text { likely to report negative emotions during those } \\
\text { interactions at both endpoints (both } \mathrm{P}<\text {.05), } \\
\text { were consistently more likely to report taking } \\
\text { medications as prescribed during weekly } \\
\text { IVR assessments, and also were less likely to } \\
\text { report breathing problems or weight gains (all } \\
\mathrm{P}<.05 \text { ). Among patients with more depressive } \\
\text { symptoms at enrollment, those randomized to } \\
\text { mHealth+CP were more likely than standard } \\
\text { mHealth patients to report excellent or very } \\
\text { good general health during weekly IVR calls. }\end{array}$ & Pubmed & $\begin{array}{l}\text { It is possible that patients were biased } \\
\text { about their medication adherence } \\
\text { reporting in order to avoid burden for } \\
\text { their Care Partner or conflict in the } \\
\text { relationship. Another limitation is that the } \\
\text { trial was conducted among VA patients, } \\
\text { nearly all of whom were men. Caregiving } \\
\text { dynamics differ by patients' demographic } \\
\text { and clinical characteristics, and future } \\
\text { studies should determine whether results } \\
\text { can be replicated in other populations, } \\
\text { including non-VA patients and women. }\end{array}$ \\
\hline
\end{tabular}




\begin{tabular}{|c|c|c|c|c|c|}
\hline Authors & Year & Title & Journal & Sample or comments & Main findings \\
\hline $\begin{array}{l}\text { Bekelman } \\
\text { D.B et al. } \\
{[26]}\end{array}$ & 2015 & $\begin{array}{l}\text { Primary results } \\
\text { of the Patient- } \\
\text { Centered } \\
\text { Disease } \\
\text { Management } \\
\text { (PCDM) for } \\
\text { heart failure } \\
\text { study a } \\
\text { randomized } \\
\text { clinical trial }\end{array}$ & $\begin{array}{l}\text { JAMA Internal } \\
\text { Medicine }\end{array}$ & $\begin{array}{l}\text { A population-based sample } \\
\text { of } 392 \text { patients with an HF } \\
\text { diagnosis from } 4 \text { Veterans Affairs } \\
\text { centers who had a Kansas City } \\
\text { Cardiomyopathy Questionnaire } \\
\text { (KCCQ) overall summary score } \\
\text { of less than } 60 \text { (heavy symptom } \\
\text { burden and impaired functional } \\
\text { status and quality of life) were } \\
\text { enrolled between May } 2009 \text { and } \\
\text { June } 2011 .\end{array}$ & $\begin{array}{l}\text { There were no significant differences in baseline } \\
\text { characteristics between patients randomized to } \\
\text { the PCDM intervention }(n=187) \text { vs usual care ( } \mathrm{n} \\
=197) \text {; Among those who screened positive for } \\
\text { depression, there was a greater improvement in the } \\
\text { Patient Health Questionnaire } 9 \text { scores after } 1 \text { year } \\
\text { in the intervention arm than in the usual care arm } \\
\text { ( } 2.1 \text { points lower, } P=.01) \text {. There was no significant } \\
\text { difference in } 1 \text {-year hospitalization rates between } \\
\text { the intervention arm and the usual care arm } \\
(29.4 \% \text { vs } 29.9 \%, P=.87)\end{array}$ \\
\hline
\end{tabular}

Lossnitzer 2015 A patient-

$\mathrm{N}$ et al. [14] centered

perspective

of treating

depressive

symptoms in

chronic heart

failure: What do

patients prefer?
Patient Educ 85 patients with CHF fulfilling the The most favored treatment option (64.7\%) was Couns. criteria of a depressive disorder according to the PHQ-9 were investigated

\section{Database}

Scopus

There are several limitations to this study. We were unable to blind participants to the intervention. Because the study was conducted among the population of US veterans, the results may not be generalizable to other health systems and populations. Additional data on aspects of implementation of the intervention may have informed why the intervention did not improve health status compared with usual care.

Pubmed First, our patient-sample was recruited from a CHF outpatient department and may therefore not be representative of CHF patients recruited from the general population or of those in primary care [33]. Second, our participation rate was only $67 \%$. Third, we included only those variables with $p<.05$ in the final multivariate regression analyses. Some variables may have been omitted on the basis of this criterion which could have been important in combination with another predictor. month follow-up. The most utilized treatments were 'regular supportive talks' ( $n=14)$ and 'heartfailure exercise group' $(n=4)$

\begin{tabular}{|c|c|c|c|c|c|}
\hline $\begin{array}{l}\text { Lundgren J } \\
\text { et al. [2] }\end{array}$ & 2015 & $\begin{array}{l}\text { Internet-based } \\
\text { cognitive } \\
\text { behavior } \\
\text { therapy for } \\
\text { patients with } \\
\text { heart failure } \\
\text { and depressive } \\
\text { symptoms: } \\
\text { A proof of } \\
\text { concept study. }\end{array}$ & $\begin{array}{l}\text { Patient Educ } \\
\text { Couns. }\end{array}$ & $\begin{array}{l}\text { Seven HF patients with } \\
\text { depressive symptoms were } \\
\text { recruited to the study. }\end{array}$ & $\begin{array}{l}\text { Based on research in HF and CBT, a nine-week } \\
\text { program was developed. The median depression } \\
\text { score decreased from baseline to the end of the } \\
\text { study (PHQ-9: 11-8.5; MADRS-S: } 25.5-16.5 \text { ) and } \\
\text { none of the depression scores worsened. Feedback } \\
\text { from health care providers required approximately } \\
\text { 3h per patient. Facilitating perceptions (e.g. } \\
\text { freedom of time) and demanding perceptions (e.g. } \\
\text { part of the program demanded a lot of work) were } \\
\text { described by the patients. }\end{array}$ \\
\hline
\end{tabular}

Pubmed The patients in the study had to make an active choice to become eligible for participation (reading the advertisement and actively going to the study website to register). Hence, there may be a sample bias in that patients with no access to the internet, low computer-skills, or no access to newspapers were not included. Furthermore, the mean age of our population was younger than the general HF population. 


\begin{tabular}{|c|c|c|c|c|c|c|c|}
\hline Authors & Year & Title & Journal & Sample or comments & Main findings & Database & Limitations \\
\hline $\begin{array}{l}\text { Kenealy } \\
\text { TW et al. } \\
\text { [35] }\end{array}$ & 2015 & $\begin{array}{l}\text { Telecare for } \\
\text { diabetes, CHF } \\
\text { or COPD: effect } \\
\text { on quality of } \\
\text { life, hospital } \\
\text { use and costs. } \\
\text { A randomised } \\
\text { controlled trial } \\
\text { and qualitative } \\
\text { evaluation. }\end{array}$ & PLoS One. & $\begin{array}{l}\text { There were } 171 \text { patients ( } 98 \\
\text { intervention, } 73 \text { control) randomly } \\
\text { assigned }\end{array}$ & $\begin{array}{l}\text { Quality of life, self-efficacy and disease- specific } \\
\text { measures did not change significantly, while } \\
\text { anxiety and depression both decreased significantly } \\
\text { with the intervention. Hospital admissions, days in } \\
\text { hospital, emergency department visits, outpatient } \\
\text { visits and costs did not differ significantly between } \\
\text { the groups. Patients at all sites were universally } \\
\text { positive. Many felt safer and more cared for, and } \\
\text { said that they and their family had learned more } \\
\text { about managing their condition. }\end{array}$ & Pubmed & $\begin{array}{l}\text { Limitations of the current study include } \\
\text { a relatively small sample size. Patients } \\
\text { randomly allocated. The same staff } \\
\text { treated both intervention and control } \\
\text { groups. In hindsight, this invited } \\
\text { contamination between groups, perhaps } \\
\text { increasing surveillance of control groups. } \\
\text { Lack of information about the numbers } \\
\text { screened prior to randomisation } \\
\text { potentially limits the generalizability of } \\
\text { findings. We have noted the technical } \\
\text { difficulties with the equipment and data } \\
\text { presented for monitoring. }\end{array}$ \\
\hline $\begin{array}{l}\text { Cockayne } \\
\text { S. et al. } \\
{[4]}\end{array}$ & 2014 & $\begin{array}{l}\text { Nurse facilitated } \\
\text { Self-management } \\
\text { support for } \\
\text { people with heart } \\
\text { failure and their } \\
\text { family carers } \\
\text { (SEMAPHFOR): } \\
\text { a randomised } \\
\text { controlled trial. }\end{array}$ & $\begin{array}{l}\text { Int J Nurs } \\
\text { Stud. }\end{array}$ & $\begin{array}{l}\text { Between August } 2006 \text { and in } \\
\text { November } 2007,260 \text { participants } \\
\text { were recruited to the study. Of the } \\
260 \text { participants, } 95 \text { were allocated } \\
\text { to the intervention group and } 165 \\
\text { to the control group. Overall, } 1079 \\
\text { participants were invited to take } \\
\text { part in the trial }\end{array}$ & $\begin{array}{l}\text { There was no evidence of a difference between the } \\
\text { groups in whether or not a patient was re-admitted } \\
\text { to hospital during the } 12 \text { month follow-up period } \\
(p=0.66) \text {. There was no evidence of a difference } \\
\text { between the treatment groups in the mean MLHF } \\
\text { scores over time }(p=0.768) \text {, the European self-care } \\
\text { questionnaire }(p=0.340) \text { or the mean HAD anxiety } \\
\text { score ( } p=0.786) \text {. However, when adjusted for } \\
\text { baseline scores the self-management group had } \\
\text { a statistically significant higher HADS depression } \\
\text { score at } 12 \text { months }(p=0.003) \text {. }\end{array}$ & Pubmed & $\begin{array}{l}\text { One limitation to the study is that } \\
\text { control patients may have asked } \\
\text { the heart failure nurse for help in } \\
\text { following the manual, which may have } \\
\text { contaminated the control group. It may } \\
\text { also be that the self-management was } \\
\text { not of sufficient duration or intensity. }\end{array}$ \\
\hline $\begin{array}{l}\text { Huffman } \\
\text { JC et al. } \\
{[25]}\end{array}$ & 2014 & $\begin{array}{l}\text { Collaborative care } \\
\text { for depression and } \\
\text { anxiety disorders in } \\
\text { patients with recent } \\
\text { cardiac events: } \\
\text { the Management } \\
\text { of Sadness } \\
\text { and Anxiety } \\
\text { in Cardiology } \\
\text { (MOSAIC) } \\
\text { randomized clinical }\end{array}$ & $\begin{array}{l}\text { JAMA } \\
\text { Intern } \\
\text { Med. }\end{array}$ & $\begin{array}{l}\text { Single-blind randomized clinical } \\
\text { trial, with study assessors blind to } \\
\text { group assignment, from September } \\
2010 \text { through July } 2013 \text { of } 183 \\
\text { patients admitted to inpatient } \\
\text { cardiac units in an urban academic } \\
\text { general hospital for acute coronary } \\
\text { syndrome, arrhythmia, or heart } \\
\text { failure and found to have clinical } \\
\text { depression, generalized anxiety } \\
\text { disorder, or panic disorder on }\end{array}$ & $\begin{array}{l}\text { Patients randomized to CC had significantly greater } \\
\text { estimated mean improvements in SF-12 MCS at } 24 \\
\text { weeks ( } 11.21 \text { points [from } 34.21 \text { to } 45.42 \text { ] in the } \\
\text { CC group vs } 5.53 \text { points [from } 36.30 \text { to } 41.83 \text { ] in } \\
\text { the control group; estimated mean difference, } 5.68 \\
\text { points [ } 95 \% \mathrm{Cl}, 2.149 .22 \text { ]; P }=.002 \text {; effect size, } \\
0.61) \text {. Patients receiving CC also had significant } \\
\text { improvements in depressive symptoms and general } \\
\text { functioning, and higher rates of treatment of a } \\
\text { mental health disorder; anxiety scores, rates of } \\
\text { disorder response, and adherence did not differ }\end{array}$ & Pubmed & $\begin{array}{l}\text { First, it occurred in an academic } \\
\text { medical center among mostly white } \\
\text { patients. Second, the intervention was } \\
\text { delivered by research clinicians who have } \\
\text { experience with the population and CC } \\
\text { programs; third, there was a single CM, } \\
\text { and our results may have been primarily } \\
\text { due to the proficiency of this clinician, } \\
\text { fourth, psychiatric diagnoses were not } \\
\text { made using formal structured clinical } \\
\text { interviews. }\end{array}$ \\
\hline
\end{tabular}




\begin{tabular}{|c|c|c|c|c|c|}
\hline Authors & Year & Title & Journal & Sample or comments & Main findings \\
\hline $\begin{array}{l}\text { Duncan, } \\
\text { K. et al. } \\
{[36]}\end{array}$ & 2014 & $\begin{array}{l}\text { Psychological } \\
\text { responses and } \\
\text { adherence to } \\
\text { exercise in heart } \\
\text { failure }\end{array}$ & $\begin{array}{l}\text { Rehabilitation } \\
\text { Nursing }\end{array}$ & $\begin{array}{l}\text { A sample of } 42 \text { patients with heart } \\
\text { failure were randomized into an } \\
\text { exercise }(\text { INV) group }(n=22) \text { and } \\
\text { an attention control }(A C) \text { group ( } \\
=20) \text {. }\end{array}$ & $\begin{array}{l}\text { Results indicate self-efficacy improved for } \\
\text { the INV group and was maintained during } \\
\text { the self-management phase. The adherence } \\
\text { subgroups demonstrated different patterns } \\
\text { for weekly exercise. Depression and } \\
\text { confusion scores improved for the high- } \\
\text { adherence group in contrast to worsening } \\
\text { for the low-adherence group. Conclusions } \\
\text { Results suggest a need for further study } \\
\text { of the psychological responses of exercise } \\
\text { adherence for patients with heart failure. }\end{array}$ \\
\hline
\end{tabular}

\begin{tabular}{|c|c|c|c|c|c|}
\hline $\begin{array}{l}\text { Gelbrich } \\
\text { G. et al. } \\
{[22]}\end{array}$ & 2014 & $\begin{array}{l}\text { Effects of } \\
\text { structured heart } \\
\text { failure disease } \\
\text { management on } \\
\text { mortality and } \\
\text { morbidity depend } \\
\text { on patients' mood: } \\
\text { results from the } \\
\text { Interdisciplinary } \\
\text { Network for Heart } \\
\text { Failure Study. }\end{array}$ & $\begin{array}{l}\text { Eur J Heart } \\
\text { Fail. }\end{array}$ & $\begin{array}{l}715 \text { participants in patients } \\
\text { enrolled after hospitalization } \\
\text { for decompensated systolic HF } \\
\text { according to their responses } \\
\text { to the } 9 \text {-item Patient Health } \\
\text { Questionnaire (PHQ-9) during an } \\
\text { observation period of } 180 \text { days. }\end{array}$ & $\begin{array}{l}\text { The composite endpoint of mortality and } \\
\text { re-hospitalization was neutral overall and } \\
\text { in all subgroups. However, HNC reduced } \\
\text { mortality risk in both depressed and non- } \\
\text { depressed patients [adjusted hazard ratios } \\
\text { (HRs) } 0.12,95 \% \text { confidence interval (CI) } \\
0.03-0.56, \mathrm{P}=0.006 \text {, and } 0.49,95 \% \mathrm{CI} 0.25- \\
0.93, \mathrm{P}=0.03, \text { respectively], but not in PHQ- } \\
\text { deniers (HR } 1.74,95 \% \mathrm{Cl} 0.77-3.96, \mathrm{P}=0.19 \text {; } \\
\mathrm{P}=0.006 \text { for homogeneity of HRs). Average } \\
\text { frequencies of patient contacts in the HNC } \\
\text { arm were } 12.8 \pm 7.9 \text { in non-depressed } \\
\text { patients, } 12.4 \pm 7.1 \text { in depressed patients, } \\
\text { and } 5.5 \pm 7.2 \text { in PHQ-deniers (P<0.001). } \\
\text { Early after decompensation, HNC reduced } \\
\text { mortality risk in non-depressed and even } \\
\text { more in depressed subjects, but not in PHQ- } \\
\text { deniers. }\end{array}$ \\
\hline
\end{tabular}

\section{Database}

Scopus (primarily Caucasian) sample which yielded low power for the assessment of changes. The exercise and adherence intervention was delivered in cohort groups, resulting in a potential correlation in the outcomes of individuals within the same small group. This exploratory analysis created additional subgroups and the sample size was not large enough to employ methods that would have allowed us to take this dependence of observations into account Data on exercise frequency was based on self-reports and may reflect over reporting of completed sessions

Pubmed We studied patients only in the first 180 days after an episode of acute cardiac decompensation for systolic HF, our results can be generalized neither to stable patients with chronic systolic HF nor to patients with HF and preserved LVEF. Another limitation concerns comparability of the depressed subgroups discussed in our study. In none of these studies was the diagnosis based on DSM-IV criteria. The definition of depressive disorder was, moreover, inconsistent. populations thus not strictly comparable. 


\begin{tabular}{|c|c|c|c|c|c|c|c|}
\hline Authors & Year & Title & Journal & Sample or comments & Main findings & Database & Limitations \\
\hline $\begin{array}{l}\text { Bekelman } \\
\text { D.B et al. } \\
\text { [6] }\end{array}$ & 2014 & $\begin{array}{l}\text { Feasibility and } \\
\text { acceptability of a } \\
\text { collaborative care } \\
\text { intervention to } \\
\text { improve symptoms } \\
\text { and quality of life } \\
\text { in chronic heart } \\
\text { failure: Mixed } \\
\text { methods pilot trial }\end{array}$ & $\begin{array}{l}\text { Journal of } \\
\text { Palliative } \\
\text { Medicine }\end{array}$ & $\begin{array}{l}\text { We conducted a prospective mixed } \\
\text { methods pilot trial. Study subjects } \\
\text { were outpatients with chronic HF } \\
\text { from a Veteran's Affairs hospital } \\
(n=15) \text { and a university hospital } \\
(n=2) \text {. }\end{array}$ & $\begin{array}{l}\text { All participants who screened positive for } \\
\text { depression on the PHQ- } 9(n=4) \text { were } \\
\text { either treated for depression or thought } \\
\text { not to have a depressive disorder and } \\
\text { treated for fatigue. Most felt the nursing } \\
\text { component was "a good source of } \\
\text { information" about diet, exercise, and self- } \\
\text { monitoring of weight and blood pressure. } \\
\text { Many said it helped with self-care. } \\
\text { Almost all patients were satisfied with the } \\
\text { frequency and phone format of CASA } \\
\text { visits. Many praised the flexibility that } \\
\text { staff offered in scheduling phone visits. } \\
\text { Most thought that CASA should ideally be } \\
\text { provided shortly after diagnosis. }\end{array}$ & Scopus & $\begin{array}{l}\text { CASA focuses primarily on symptoms } \\
\text { and quality of life. Other components } \\
\text { of palliative care, such as advance care } \\
\text { planning and spiritual care, are not } \\
\text { structured into the intervention. Finally, } \\
\text { as the majority of recruitment took } \\
\text { place at a Veterans Affairs hospital, all } \\
\text { the participants were male, and we } \\
\text { did not learn if females might respond } \\
\text { differently to the intervention. }\end{array}$ \\
\hline $\begin{array}{l}\text { Evangelista } \\
\text { LS et al. } \\
\text { [37] }\end{array}$ & 2014 & $\begin{array}{l}\text { Does the type } \\
\text { and frequency } \\
\text { of palliative care } \\
\text { services received } \\
\text { by patients with } \\
\text { advanced heart } \\
\text { failure impact } \\
\text { symptom burden }\end{array}$ & $\begin{array}{l}\text { Journal of } \\
\text { Palliative } \\
\text { Medicine }\end{array}$ & $\begin{array}{l}\text { This descriptive-exploratory } \\
\text { study was conducted at a single } \\
\text { university affiliated medical center. } \\
\text { Participants were recruited from } \\
\text { the inpatient setting through HF } \\
\text { provider referrals. During the five- } \\
\text { month study recruitment period, } \\
57 \text { patients were referred by their } \\
\text { HF provider; } 42 \text { ( } 73 \% \text { ) provided } \\
\text { informed consent, but only } 36 \\
\text { (85.7\%) completed the initial PC } \\
\text { consultation. }\end{array}$ & $\begin{array}{l}\text { We found that ongoing PC support } \\
\text { beyond the initial PC consultation resulted } \\
\text { in greater reductions in symptom burden, } \\
\text { including pain and depression, confirming } \\
\text { that on-going PC provides clinicians with } \\
\text { the opportunity to focus on the needs } \\
\text { and preferences of greatest importance } \\
\text { to patients and families are more likely to } \\
\text { result in better outcomes. }\end{array}$ & Scopus & $\begin{array}{l}\text { First, as expected with descriptive, } \\
\text { exploratory studies, causation cannot } \\
\text { be inferred. We cannot say that } \\
\text { the number of PC referrals actually } \\
\text { resulted in reduced symptom burden. } \\
\text { Second, the generalizability of our } \\
\text { findings is limited because the sample } \\
\text { is from a single university affiliated } \\
\text { medical center; patients were younger } \\
\text { on average compared to patients with } \\
\text { HF in the community. Third, we did not } \\
\text { have a mechanism to verify the time } \\
\text { spent on individual PC services during } \\
\text { the follow-up visits. Last, our study did } \\
\text { not have a control group. }\end{array}$ \\
\hline
\end{tabular}




\begin{tabular}{|c|c|c|c|c|}
\hline Authors & Year & Title & Journal & Sample or comments \\
\hline $\begin{array}{l}\text { Tully PJ et } \\
\text { al. [11] }\end{array}$ & 2014 & $\begin{array}{l}\text { A dynamic view } \\
\text { of comorbid } \\
\text { depression and } \\
\text { generalized anxiety } \\
\text { disorder symptom } \\
\text { change in chronic } \\
\text { heart failure: the } \\
\text { discrete effects of } \\
\text { cognitive behavioral } \\
\text { therapy, exercise, } \\
\text { and psychotropic } \\
\text { medication. }\end{array}$ & $\begin{array}{l}\text { Disabil } \\
\text { Rehabil. }\end{array}$ & $\begin{array}{l}\text { Total } 29 \text { HF patients under } \\
\text { psychiatric management } \\
\text { underwent primary depression } \\
\text { cognitive behavioral therapy (CBT; } \\
\text { n¹/415) or primary generalized } \\
\text { anxiety disorder (GAD) CBT } \\
\text { (n1/414), and participated in a } \\
\text { community exercise program } \\
\text { and standard physician care. } \\
\text { Repeated measures analysis of } \\
\text { variance assessed Patient Health } \\
\text { Questionnaire (PHQ-9) and GAD-7 } \\
\text { symptom change pre- and post- } \\
\text { CBT treatment, and assessed the } \\
\text { interaction effects of treatment } \\
\text { type, exercise, anti-depressant } \\
\text { and anxiolytic. }\end{array}$ \\
\hline
\end{tabular}

al. [38] psychological

telemonitoring and

telecare of high

risk heart failure patients.
J Telemed Eighty patients were randomized Telecare.

before hospital discharge to a usual care group ( $n \frac{1}{4} 40$ : follow up at the outpatient clinic) or to an integrated management group ( $n 1 / 440$ : patients learned to use a handheld PDA and kept in touch daily with the monitoring centre) At enrolment, the groups were similar for all clinical variables.

\section{Main findings}

With respect to PHQ total scores, none of the main effects were significant (CBT treatment type $\mathrm{p}^{1} / 40.19$, exercise

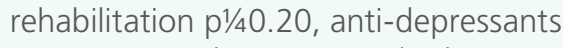
$p^{1} / 40.46$, anxiolytics $p^{1 / 40.80}$ ). There was however a significant time and treatment interaction effect showing greater reduction in depression symptoms that favored the GAD CBT group (F(1, 24) $1 / 44.52, p^{1} \frac{1}{4} 0.04$, partial2p $\left.1 / 40.16\right)$.

At one-year follow-up, integrated management patients showed better adherence, reduced anxiety and depression, and lower NYHA class and plasma levels of BNP with respect to the usual care patients (e.g. NYHA class 2.1 vs $2.4, P<0.02$ ). In heart failure patients at high risk of relapse, the regular acquisition of simple clinical information and the possibility for the patient to contact the clinical staff improved drug titration, produced better psychological status and quality of life, and reduced hospitalizations for heart failure.

\section{Database} Limitations

Pubmed

Other potential sampling limitations include that depression and anxiety disorders are frequently under-recognized [67]. For example, as many as $27 \%$ of cardiac patients are not assessed by routine screening protocols [68] and severely depressed patients are less likely to prefer counseling than anti-depressants 48]. Treatment was not allocated according to a randomization process, but rather, based on consultation and patient preference.

Pubmed First, telemonitoring does not imply telecare: this may explain the failure of ambitious, multicentre studies and the better results of local experiences, where patients are likely to benefit from individual interaction with dedicated, well-trained and specialized care providers. Second, a range of different variables has been used in telemonitoring: remote checking of bodyweight, blood pressure, heart rate, even natriuretic peptides, have all been tested to prevent hospital admissions Study patients represent a very small number of the patient panels of a given primary care provider, and thus the potential for contamination is low. The intervention is multimodal, and we may not know the most important components of the intervention if it is successful. 


\begin{tabular}{|c|c|c|c|c|c|c|c|}
\hline Authors & Year & Title & Journal & Sample or comments & Main findings & Database & Limitations \\
\hline $\begin{array}{l}\text { Chung } \mathrm{H} \text {. } \\
\text { et al. [39] }\end{array}$ & 2013 & $\begin{array}{l}\text { Early e experience } \\
\text { of a pilot } \\
\text { intervention for } \\
\text { patients with } \\
\text { depression and } \\
\text { chronic medical } \\
\text { illness in an urban } \\
\text { ACO }\end{array}$ & $\begin{array}{l}\text { General } \\
\text { Hospital } \\
\text { Psychiatry }\end{array}$ & $\begin{array}{l}\text { Patients with chronic illness } \\
\text { (diabetes mellitus, coronary artery } \\
\text { disease and/or congestive heart } \\
\text { failure) and comorbid depressive } \\
\text { symptoms (Patient Health } \\
\text { Questionnaire [PHQ]9 score } \geq 10 \text { ) } \\
\text { were enrolled. Seventy-nine } \\
\text { eligible patients were offered } \\
\text { enrollment in the program with } \\
12 \text { refusals. Sixty-seven patients } \\
\text { enrolled during the pilot period, } \\
\text { and } 6 \text { patients disenrolled prior to } \\
8 \text { weeks. Results for } 61 \text { patients }\end{array}$ & $\begin{array}{l}\text { Forty-four percent of patients }(n=61) \\
\text { achieved a depression response. In a } \\
\text { diabetes subgroup with depression and } \\
\text { glycosylated hemoglobin level HbA1c } \\
>8(n=21), 33 \% \text { had a depression } \\
\text { response with a minimum } 0.5 \% \text { HbA1c } \\
\text { reduction. Among a subgroup }(n=25) \\
\text { with Framingham risk score }>15 \% \text { and } \\
\text { depression, mean PHQ9 depression } \\
\text { scores and mean Framingham scores were } \\
\text { reduced by } 35 \% \text { and } 34 \% \text {, respectively. }\end{array}$ & Scopus & $\begin{array}{l}\text { The sample size was small and recruited } \\
\text { through data mining and PCP referral. } \\
\text { There was no control group. The patient } \\
\text { survey results represented only } 38 \% \text { of the } \\
\text { patient sample and may result in a positive } \\
\text { bias. The findings may not be generalizable } \\
\text { to systems that lack centralized care } \\
\text { management resources or accountable } \\
\text { care payment arrangements. }\end{array}$ \\
\hline $\begin{array}{l}\text { Bekelman } \\
\text { DB et al. } \\
\text { [5] }\end{array}$ & 2013 & $\begin{array}{l}\text { Patient- } \\
\text { centered disease } \\
\text { management } \\
\text { (PCDM) for heart } \\
\text { failure: study } \\
\text { protocol for } \\
\text { a randomised } \\
\text { controlled trial. }\end{array}$ & $\begin{array}{l}\text { BMC } \\
\text { Cardiovasc } \\
\text { Disord. }\end{array}$ & $\begin{array}{l}\text { Patients with a HF diagnosis at } \\
\text { four VA Medical Centers were } \\
\text { identified through population } \\
\text { based sampling. Patients with } \\
\text { a Kansas City Cardiomyopathy } \\
\text { Questionnaire (KCCQ, a measure } \\
\text { of HF-specific health status) } \\
\text { score of < } 60 \text { (heavy symptom } \\
\text { burden and impaired quality of } \\
\text { life) were invited to enroll in the } \\
\text { PCDM trial. Enrolled patients were } \\
\text { randomized to receive usual care } \\
\text { or the PCDM intervention. }\end{array}$ & $\begin{array}{l}\text { The primary study outcome is change in } \\
\text { overall KCCQ score. Secondary outcomes } \\
\text { include depression, medication adherence, } \\
\text { guideline-based care, hospitalizations, and } \\
\text { mortality. }\end{array}$ & Pubmed & $\begin{array}{l}\text { Study patients represent a very small } \\
\text { number of the patient panels of a given } \\
\text { primary care provider, and thus the } \\
\text { potential for contamination is low. The } \\
\text { intervention is multimodal, and we may } \\
\text { not know the most important components } \\
\text { of the intervention if it is successful. }\end{array}$ \\
\hline
\end{tabular}




\section{Discussion}

Use of telephone calls aiming support and monitoring is extensively reported in literature, reaching satisfactory results in depression management and in general clinical symptoms (Huffman et al., 2014; Kalter-Leibovici et al., 2017; Piette et al., 2015). As an example of this, Chung et al. (2013) performed a pilot study through a telephone therapy program and obtained a regression of PHQ-9 (Patient Health Questionnaire 9) index in 15\% of studied patients, corroborating the study of Gelbrich et al. (2014) in which patients were accompanied and evaluated through telephone regarding selfmonitoring, and were regularly encouraged to face individual problems. PHQ-9 is a nine items instrument self-administrated and projected to detect depression in different populations (Lundgren et al., 2015). Results are shown as an effective strategy of management to HF depressed patients, once they significantly improved surviving during first 180 days after discharge from hospital. Piette et al. (2015) also demonstrated the use of interactive telephonic calls, in which patients received personalized counseling about self-management. Among patients with higher level of depressive symptoms participating the study, those randomized were the ones who reported an excellent or very good improvement in general health. Similar strategies were used by Kalter-Leibovici et al. (2017) Bekelman et al. (2013) and Villani et al. (2014) showed that the group that applied the management presented greater adhesion rates, clinical and psychological status improvement, recovering of relevant prognostic indexes, as ventricular function and BNP levels, and reduction of hospitalizations due heart failure. Favorable results were attributed to daily monitoring.

Cognitive behavioral therapy in depression treatment, which can be through telephone, or group or individual therapy, also resulted in mental health improvement among HF patients (Tully et al., 2015). In Huffman et al. (2014) study, during 24 weeks, the participants were randomized in a group that received cognitive behavioral intervention based on a phone call, trying to reach depressive and anxiety disorders, and in a control group, which had increased usual care. There was improvement in quality of life and mental health (Short Form-12 Mental Component Score [SF-12 MCS]), compared to groups using a random effect model. Patients who received cognitive behavioral intervention also had improvement in depressive symptoms and general functioning, obtaining higher treatment rates of a mental disorder.

Kenealy et al. (2015) demonstrated that patients submitted to habitual care and encouraged to daily insert data in an electronic device had anxiety and depression levels significantly reduced, compared to patients from control group. Hospital admissions, days in hospital, visits to emergency department, ambulatorial visits and costs did not differ significantly among groups. Positive results were attributed to greater security and more care by the patient, and better family understanding about condition management.

Bekelman et al. (2014) associated different aspects: nurse telephone calls with evaluation of structured symptoms, and guidelines to relieve shortness of breath, fatigue, pain, or depression; structured counseling through telephone aiming disease adjustment; and weekly team reunions with a specialist in palliative care, cardiologist and primary attention doctor focused on medical recommendations to primary care providers. These aspects are being evaluated, with promising initial results on quality of life, decreased hospitalizations, depression and anxiety.

Duncan, Pozehl, Hertzog and Norman (2014) show the HEART Camp, a program that involves aerobic and anaerobic exercises, and a social cognitive therapy, which postulates that self-efficiency is derived from interrelation of behavior, cognition, and personal and environmental influence (Bandura, 1997; Duncan et al., 2014). HEART Camp sample 
consisted of 42 patients randomized in two groups and the feedback was composed by weekly graphic of participation in exercise (frequency, duration, intensity). This study did not found differences in humor for exercise group and control group, after some time. The research about exercise in cardiac population has reported improvement of psychological responses, more notably for depression and anxiety (Evangelista, Lião, Motie, Michelis, BallardHernandez \& Lombardo, 2014). Memory lack in states of humor can be reflex of a low frequency of group and the fact that these results are preliminary results.

The participation of a multidisciplinary team is present in most care programs aimed in patients with HF and depression. Psychologists, psychiatrics, nurses, doctors and professionals specialized in palliative care, when actuate together, promote security and a higher attention level, resulting in treatment quality improvement, as well as improvement of disease symptoms (Bekelma et al., 2014; Kalter-Leibovici, 2017; Kemper et al., 2016).

Patient engagement is of total importance for treatment efficacy, Cockayne, Pattenden, Worthy, Richardson and Lewin (2014) and Evangelista et al. (2014) with an intervention based on palliative care, in which the specialist performed physical and psychosocial evaluation and discussions about care planning, and worked together with the participants to develop a treatment plan centered in patient and family, which improve the involvement of patients and their families in caring decisions. The continuous and centered support resulted in greater reductions in symptoms load, including pain and depression, confirming that palliative care offers to clinicians the opportunity to focus in needs and preferences of greater importance to patients and families, leading to better treatment results.

Pharmacological treatment with selective serotonin reuptake inhibitor seems to be safe for patients with cardiac insufficiency, Lundgren et al.
(2015) and O'Connor et al. (2010) but the effect in depression remains uncertain (Lundgren et al., 2015; Woltz et al., 2012). A great double blind study controlled by placebo, comprising 469 patients, did not show depression improvement in patients with HF after antidepressant use (Lossnitzer et al., 2015; O'Connor et al., 2010).

Similar results were reported by some studies, Gelbrich et al. (2014) and Angermann et al. (2007) in which antidepressant did not show positive effects in patients with cardiovascular diseases and comorbid depression. Kemper KJ, et al. (2016) add to actual data that pharmacological intervention had uncomplete impact on stress and depression in patient with $\mathrm{HF}$.

In other hand, Lossnitzer et al. (2015) reveal that many patients with HF have objection to antidepressant because they are concerned about adverse effects or negative interaction of medication. This is consistent to recent studies that suggest cardiovascular side effects of antidepressants in patients with HF (Lossnitzer et al., 2015; Tousoulis et al., 2010). Still, this study reports vantages of successful psychotherapy compared to antidepressant pharmacotherapy in treatment of depression associated to HF.

In this context, new approaches are necessary to favor self-management and, thus, improve psychosocial and behavioral factors that affect quality of life in patients with HF (Kemper et al., 2016; Du et al., 2011). The search for a correct treatment of cardiac insufficiency involved a great number of research groups, but, in reality, patients are still not treated as they should (Villani et al., 2014).

\section{Conclusion}

Facing all analyzed data, one can infer that the best way to manage a patient with heart failure and depression is through the combination of pharmacological and non-pharmacological treatments. Nevertheless, psychotherapy, as cognitive behavioral therapy; self-management strategies; and palliative 
caring, allied to involvement of a multi-disciplinary team composed by doctors, nurses, psychologists, psychiatrists, and other professionals specialized in palliative caring, are, notably, the most effective way to manage this class of patient. On the other hand, information about pharmacological interventions applied in this context is still scarce, which impedes the formulation of a coherent answer to the question of this study.

Thus, the limitation of this study can be attributed to data lack about antidepressant efficacy in patients with HF, as well as other studies show (Gottlieb et al., 2007; Lesperánce et al., 2003; Lossnitzer et al., 2015; O'Connor et al., 2010). This efficacy was approached in some selected studies, but it was partially investigated, remaining uncertain the antidepressant effects in HF. Thus, new researches that aims to evaluate the correct management of HF associated to depression, combining psychosocial and pharmacological interventions, are necessary.

\section{Acknowledgements}

We thank the research group of the Federal University of Cariri (UFCA) and Faculty of Medicine of Juazeiro do Norte - Estácio FMJ/National Council for Scientific and Technological Development (CNPq). We would also like to thank the Laboratory of Scientific Writing (LABESCl), Federal University of Cariri (UFCA).

\section{Contributors}

Mendes and Feitoza mapping and categorization of information.

Ribeiro and Lima: data analysis.

Pimentel: review of the information and formatting the article.

Rolim Neto: responsible for study design.

All authors contributed to and have approved the final manuscript.

\section{Funding}

We acknowledge the funding by the Research Group: Suicidology-Federal University of Ceará UFC/National Council for Scientific and Technological Development-CNPq - body linked to the Ministry of Science, Technology and Innovation to encourage research in Brazil.

\section{References}

- McMurray J.J., A, S., A, S. D., A, A., B, M., D, K., F, V., F, G., F, C., G, M. A., J, T., K, L., L, G. Y., M, A. P., P, A., P, B. M., P, B. A., R, P. K., R, F. H., S, J., S, P., S, J., T, P. T., V, A. A., Z, F., \& Z, A. (2012). ESC Guidelines for the diagnosis and treatment of acute and chronic heart failure 2012: The Task Force for the Diagnosis and Treatment of Acute and Chronic Heart Failure 2012 of the European Society of Cardiology, Developed in collaboration with the Heart. European Heart Journal, 33(14), 1787-1847. From https://doi.org/10.1093/eurheartj/ehs104

- Lundgren, J., A, G., D, O., J, T., K, A. K., \& J, P. (2015). Internetbased cognitive behavior therapy for patients with heart failure and depressive symptoms: a proof of concept study. Patient Education Counseling, 98(8), 935-942. From https://doi. org/10.1016/j.pec.2015.04.013

- Jaarsma, T., H, R., T, F., A, H. H., D, K., \& D, J. (2000). Self-care and quality of life in patients with advanced heart failure: the effect of a supportive educational intervention. Heart \& Lung 29(5), 319-330. From https://doi.org/10.1067/mhl.2000.108323

- Cockayne, S., P, J., W, G., R, G., \& L, R. (2014). Nurse facilitated Self-management support for people with heart failure and their family carers (SEMAPHFOR): a randomised controlled trial. Internationla Journal of Nursing Studies, 51(9), 1207-1213. From https://doi.org/10.1016/j.ijnurstu.2014.01.010

- Bekelma, D. B., P, M. E., S, M. D., N, K., H, B., M, C., L, K. G., P, J., H, P., \& R, J. S. (2013). Patient-centered disease management (PCDM) for heart failure: Study protocol for a randomised controlled trial. BMC Cardiovascular Disorders, 13(49), 1-6. From https://doi.org/10.1186/1471-2261-13-49

- Bekelma, D. B. H, S., N, C. T., M, D. S., M, P., M, C., H, B., L, K. A., \& H, P. A. (2014). Feasibility and Acceptability of a Collaborative Care Intervention To Improve Symptoms and Quality of Life in Chronic Heart Failure: Mixed Methods Pilot Trial. Journal of Palliative Medicine, 17(2), 145-151. From https:// doi.org/10.1089/jpm.2013.0143 
- Greene, S., F, G. C., V, M., K, S. S, B, J., \& G, M. (2015). The vulnerable phase after hospitalization for heart failure. Nature Reviews. Cardiology, 12(4), 220-229. From https://doi. org/10.1038/nrcardio.2015.14

- Tisminetzky, M., M, D., E, N., S, J. S., Y, J., G, E., G, J., \& G, R. (2015). Thirty day hospital re-admissions in patients with non ST-segment elevation acute myocardial infarction. The American Journal of Medicine, 128(7), 760-765. From https:// doi.org/10.1016/j.amjmed.2015.01.022

- Kemper, K. J., C, C., M, B., \& B, P. (2016). Integrative Medical Care Plus Mindfulness Training for Patients With Congestive Heart Failure. Journal of Evidence-based. Complementary \& Alternative Medicine, 21(4), 282-290. from https://doi. org/10.1177/2156587215599470

- McMurray, J. J. A, S., A, S. D., A, A., B, M., D, K., F, V., F, G., F, C., G, M. A., J, T., K, L., L, G. Y., M, A. P., P, A., P, B. M., P, B. A., R, P. K., R, F. H., S, J., S, P., S, J., T, P. T., V, A. A., Z, F., \& Z, A. (2012). ESC guidelines for the diagnosis and treatment of acute and chronic heart failure 2012. European Journal of Heart Failure, 14(8), 803-869. From https://doi.org/10.1093/eurjhf/hfs105

- Tully, P. J., S, T., B, J., \& R, C. (2015). A dynamic view of comorbid depression and generalized anxiety disorder symptom change in chronic heart failure: the discrete effects of cognitive behavioral therapy, exercise, and psychotropic medication. Disability and Rehabilitation, 37(7), 585-592. From https://doi.org/10.3109/09 638288.2014 .935493

- Bleumink, G., K, A. M., S, M. C., S, S. M., H, A., D, J. W., W, J. C., \& S, B. H. (2004). Quantifying the heart failure epidemic: prevalence, incidence rate, lifetime risk and prognosis of heart failure. European Heart Journal, 25(18), 1614-1619. From https:// doi.org/10.1016/j.ehj.2004.06.038

- Juenger, J., S, D., K, S., H, A., Z, C., H, W., \& H, M. (2002). Health related quality of life in patients with congestive heart failure: comparison with other chronic diseases and relation to functional variables. Heart, 87(3), 235-241. From https://www. ncbi.nlm.nih.gov/pmc/articles/PMC1767036/pdf/hrt08700235. pdf

- Lossnitzer, N., H, W., S, J. H., T, T., F, L., \& W, B. (2015). A patient-centered perspective of treating depressive symptoms in chronic heart failure: what do patients prefer? Patient Education and Counseling, 98(6), 783-787. From https://doi.org/10.1016/j. pec.2015.02.008

- Adams, K., F, G. C., E, C. L., L, T. H., C, M. R., A, W. T., B, R. L., G, M., \& H, D. P. (2005). Characteristics and outcomes of patients hospitalized for heart failure in the United States: rationale, design, and preliminary observations from the first 100,000 cases in the Acute Decompensated Heart Failure National Registry (ADHERE). American Heart Journal, 149(2), 209-216. From https://doi.org/10.1016/j.ahj.2004.08.005
- Chamberlain, A. M., S, J. L., G, Y., M, S. M., B, C. M., D, S. M., R, W. A., F, L J., J, R., W, S. A., \& R, V. L,. (2015). Multimorbidity in heart failure: a community perspective. The American Journal of Medicine, 128(1), 38-45. From https://doi.org/10.1016/j. amjmed.2014.08.024

- Johansson, P., D, U., \& B, A. (2006). The measurement and prevalence of depression in patients with chronic heart failure. Progress in Cardiovascular Nursong, 21(1), 28-36. From https:// doi.org/10.1111/j.0197-3118.2006.04644.x

- Rutledge, T., R, V., L, S., G, B. \& M, P. (2006). Depression in heart failure. A meta-analytic review of prevalence, intervention effects, and associations with clinical outcomes. Journal the American College of Cardiology, 48(8), 1527-1537. From https:// doi.org/10.1016/j.jacc.2006.06.055

- Ayuso-Mateos, J., V, J. L., D, C., L, V., D, O. S., C, P., W, C., L, L., P, H., D, G., \& W, G. (2001). Depressive disorders in Europe: prevalence figures from the ODIN study. The British Journal of Psychiatry, 179(4), 308-316. From https://doi.org/10.1192/ bjp.179.4.308

- Parissis, J., F, K., P, I., \& K, D. (2005). Depression in chronic heart failure: novel pathophysiological mechanisms and therapeutic approaches. Expert Opinion on Investigational Drugs, 14(5), 567-577. Fom https://doi.org/10.1517/13543784.14.5.567

- Angermann, C., G, G., S, S., S, M., D, J., E, G., \& F, H. (2011). Somatic correlates of comorbid major depression in patients with systolic heart failure. International Journal of Cardiology, 147(1), 66-73. From https://doi.org/10.1016/j.ijcard.2009.07.044

- Gelbrich, G., S, S., K, S., F, H., P, C., H, P. U., E, G., \& A, C. E. (2014). Effects of structured heart failure disease management on mortality and morbidity depend on patients' mood: Results from the Interdisciplinary Network for Heart Failure Study. European Journal of Heart Failure, 16(10), 1133-1141. From https://doi.org/10.1002/ejhf.150

- Jünger, J., S, D., M, T., R, G., Z, C., H, A., Z, S., H, W., \& H, M. (2005). Depression increasingly predicts mortality in the course of congestive heart failure. European Journal of Heart Failure, 7(2), 261-267. From https://doi.org/10.1016/j.ejheart.2004.05.011

- Jiang, W., A, J., C, E., K, M., G, L. H., C, M. S., B, M. A., D, C., C, R. M., K, R. R., \& O, C. M. (2001). Relationship of depression to increased risk of mortality and rehospi- talization in patients with congestive heart failure. Archives of Internal Medicine, 161(15), 1849-1856. From https://doi.org/10.1001/archinte.161.15.1849

- Huffman, J. C., M, C. A., B, S. R., C, C. M., D, C. M., H, B. C., S, L., R, B. L., \& J, J. L. (2014). Collaborative care for depression and anxiety disorders in patients with recent cardiac events: the management of sadness and anxiety in cardiology (MOSAIC) randomized clinical trial. JAMA Internal Medicine, 174(6), 927935. From https://doi.org/10.1001/jamainternmed.2014.739 
- Bekelman, D. B., P, M. E., C, E. P., S, M. D., N, K. M., H, B., M, C. F., L, K. G., G, K., H, P. A., \& R, J. S. (2015). Primary results of the Patient-Centered Disease Management (PCDM) for heart failure study: a randomized clinical trial. JAMA Internal Medicine, 175(5), 725-732. From https://doi.org/10.1001/ jamainternmed.2015.0315

- Thombs, B., D, P., C, J. C., W, M. A., F, N., M, A. J., Z, M., E, C., L, B. B., S, C. G., S, K., \& Z, R. C. (2008). Depression screening and patient outcomes in cardiovascular care: a systematic review. JAMA, 300(18), 2161-2171. From https://doi.org/10.1001/ jama.2008.667

- Woltz, P. C., C, D. W., F, E., S, H., A, B., \& T, S. A. (2012). Effects of interventions on depression in heart failure: a systematic review. Heart \& Lung: The Journal of Acute and Critical Care, 41(5), 469483. From https://doi.org/10.1016/j.hrtlng.2012.06.002

- Dekker, R. L. (2011). Cognitive therapy for depression in patients with heart failure: a critical review. Heart Failure Clinics, 7(1), 127-141. From https://dx.doi.org/10.1016\%2Fj.hfc.2010.10.001

- Gary, R. A., G., D, S. B., H, M. K., M, D. L., \& S, A. L. (2010). Combined exercise and cognitive behavioral therapy improves outcomes in patients with heart failure. Journal of Psychosomatic Research, 69(2), 119-131. From https://doi.org/10.1016/j. jpsychores.2010.01.013

- Sullivan, M. J., W, L., T, J., B, J., C, A., M, V., J, D., K, M. W., R, B., B, H. B., A, K., \& C, M. S. (2009). The support, education, and research in chronic heart failure study (SEARCH): a mindfulnessbased psycheducational intervention improves depression and clinical symptoms in patients with chronic heart failure. American Heart Journal, 157(1), 84-90. From https://doi. org/10.1016/j.ahj.2008.08.033

- Dekker, R. L., M, D.K., P, A. R., \& L, T. A. (2012). Cognitive therapy improves threemonth outcomes in hospiltalized patients with heart failure. Journal of Cardiac Failure, 18(1), 10-20. From https://dx.doi.org/10.1016\%2Fj.cardfail.2011.09.008

- Kalter-Leibovici, O., F, D., F, L. S., K, G., Z, A., M, H., B, M., S, B. G., F, N., C, T., A, E., G, A., G, D., A, M., M, S., S, M., \& S, H. (2017). Disease management in the treatment of patients with chronic heart failure who have universal access to health care: a randomized controlled trial. BMC Medicine, 15(90), 1-13. From https://doi.org/10.1186/s12916-017-0855-z

- Piette, J., D. S, D., M, N., C, J., T, R. B., A, D. C., F, L., \& A, J. E. (2015). A mobile health intervention supporting heart failure patients and their informal caregivers: A randomized comparative effectiveness trial. Journal of Medical Internet Research, 17(6), e142 . From https://dx.doi.org/10.2196\%2Fjmir.4550
- Kenealy, T. W., P, M. J. G., R, A. P. B., D, R. N., S, N. F., H, J. K. H., M, S. C., \& R, H. H. (2015). Telecare for diabetes, CHF or COPD: Effect on quality of life, hospital use and costs. A randomised controlled trial and qualitative evaluation. PLoS One, 10(3), 1-21. From https://dx.doi.org/10.1371\%2Fjournal.pone.0116188

- Duncan, K., P, B., H, M. \& N, J. F. (2014). Psychological responses and adherence to exercise in heart failure. Rehabilitation Nursing, 39(3), 130-139. From https://doi.org/10.1002/rnj.106

- Evangelista, L. S., L, S., M, M., D, N., B, J., \& L, D. (2014). Does the Type and Frequency of Palliative Care Services Received by Patients with Advanced Heart Failure Impact Symptom Burden? Journal of Palliative Medicine, 17(1), 75-79. From https://dx.doi. org/10.1089\%2Fjpm.2013.0231

- Villani, A., M, G., C, A., D, R. F., B, L., B, G., M, E., \& P, G. (2014). Clinical and psychological telemonitoring and telecare of high risk heart failure patients. Journal of Telemedicine and Telecare, 20(8), 468-475. From https://doi.org/10.1177/1357633X14555644

- Chung, H., K, A., N, C. J., C, J., R, S, O, M. A., R, D. (2013). Early experience of a pilot intervention for patients with depression and chronic medical illness in an urban ACO. General Hospital Psychiatry, 35(5), 468-471. From https://doi.org/10.1016/j. genhosppsych.2013.04.014

- Bandura, A. (1997). Self-efficacy: the exercise of control. New York: W.H. Freeman.

- O'Connor, C., J, W., K, M., S, S. G., C, M. S., C, D. D., Z, B., S, W. G., A, R. M, R, S. K., \& K, R. (2010). Safety and efficacy of sertraline for depression in patients with heart failure. Journal of the American College of Cardiology, 56(9), 692-699. From https://doi.org/10.1016/j.jacc.2010.03.068

- Angermann, C., G, G., S, S., F, A., D, J., F, H., \& E, G. (2007). Rationale and design of a randomised, controlled, multicenter trial investigating the effects of selective serotonin re-uptake inhibition on morbidity, mortality and mood in depressed heart failure patients (MOOD-HF). European Journal of Heart Failure, 9(12), 1212-1222. From https://doi.org/10.1016/j. ejheart.2007.10.005

- Tousoulis, D., A, A. S., A, C., S, C., S, E., S, G., S, P., P, A., K, P., \& S, C. (2010). Role of depression in heart failure-choosing the right antidepressive treatment. International Journal of Cardiology, 140(1), 12-8. From https://doi.org/10.1016/j. ijcard.2009.05.022 
- Du, H. Y., N, P.J., Z, R., D, R., S, Y., E, B., C, D. C., M, P. S., \& D, P. M. (2011). An intervention to promote physical activity and self-management in people with stable chronic heart failure The Home-Heart-Walk study: study protocol for a randomized controlled trial. Trials, 12(63), 1-6. From https://doi. org/10.1186/1745-6215-12-63

- Gottlieb, S., K, W. J., T, S. A., K, S., V, M. R., G, N., M, J., C, M., \& M, S. (2007). A double-blind placebo-controlled pilot study of controlled-release paroxetine on depression and quality of life in chronic heart failure. American Heart Journal, 153(5), 868-873. From https://doi.org/10.1016/j.ahj.2007.02.024

- Lesperánce, F., F, N., L, M. A., W, M., L, S., C, A., T, M., \& R, J. L. (2003). An open-label study of nefazodone treatment of major depression in patients with congestive heart failure. The Canadian Journal of Psychiatry, 48(10), 695-701. From https:// doi.org/10.1177/070674370304801009

Publish in International Archives of Medicine

International Archives of Medicine is an open access journal publishing articles encompassing all aspects of medical science and clinical practice. IAM is considered a megajournal with independent sections on all areas of medicine. IAM is a really international journal with authors and board members from all around the world. The journal is widely indexed and classified Q2 in category Medicine. 